\title{
Relationship between Ovarian Progestin Secretion and Corpora Lutea Function in Pregnat Rats*
}

\author{
KiYohisa UCHIDA, MASUMI KADOWAKI, YASUHARU NOMURA, \\ KENJI MIYATA AND TAMOTSU MIYAKE \\ Shionogi Research Laboratory, Shionogi \& Co., Ltd., Fukushima-ku, Osaka
}

\begin{abstract}
Synopsis
Progesterone and 20 $\alpha$-hydroxypregn-4-en-3-one (20 $\alpha$-OH-P) secretory rates of rat ovaries were measured during pregnancy and pseudopregnancy. In the pregnant rats, $20 \alpha$-hydroxysteroid dehydrogenase $(20 \alpha-\mathrm{OH}-\mathrm{SDH})$ activity of the ovaries, wet weights of corpora lutea and their concentrations of cholesterol, progesterone and $20 \alpha-\mathrm{OH}-\mathrm{P}$ were also determined. Progesterone secretion increased but fluctuated during pregnancy: a small rise on Day 4 was followed by a fall on Day 7, and a marked rise on Days 13 to 15 was followed by a great fall on Days 20 to 23 (the day sperm was found in vaginal smears was designated as Day 1). $20 \alpha-\mathrm{OH}-\mathrm{P}$ secretion decreased throughout pregnancy, although a small rise appeared around Day 15. The second peak of progesterone secretion and the small peak of $20 \alpha-\mathrm{OH}-\mathrm{P}$ occurred in coincidence with the growth of corpora lutea which had remained fairly constant by Day 10 . After the cessation of corpora lutea growth on Day 16, both progestin secretions turned to decrease. Cholesterol concentration in corpora lutea, which remained relatively low during the first half of pregnancy but gradually increased with a gentle slope by Day 17 , suddenly doubled the value on Day 18 when progesterone secretion kept decreasing. Progesterone secretion continued to decrease until the day of parturition (Days 22 to 23). $20 \alpha-\mathrm{OH}-\mathrm{P}$ began to increase on Day 22 in accordance with the increase of $20 \alpha-\mathrm{OH}-\mathrm{SDH}$ activity in corpora lutea, which had never appeared before Day 20. After parturition, progesterone secretion began to increase on the third day, conversely with a rapid drop in $20 \alpha-\mathrm{OH}-\mathrm{P}$ secretion in lactating rats. Corpora lutea progesterone, which showed the highest value on Days 5 to 8 of pregnancy followed by a gradual decrease to the lowest on Day 23, did not appear to play a special part in the regulation of progesterone secretion. In pseudopregnancy, progesterone secretion increased beginning 3 to the maximum on Day 7 and declined thereafter to Day 14, while $20 \alpha-\mathrm{OH}-\mathrm{P}$ secretion decreased during the same period of time, but the secretory rate was generally higher than that in pregnancy, so that a higher ratio of progesterone to total progestin (progesterone plus $20 \alpha-\mathrm{OH}-\mathrm{P}$ ) was obtained in pregnancy than in pseudopregnancy.
\end{abstract}

It has been well established that progesterone is essential for the maintenance of pregnancy and mainly secreted from the functional corpora lutea. Eto et al. (1962) first demonstrated a marked increase in ovarian progesterone secretion in pregnant rats. Later, Fajor

Received for publication December 18, 1970.

* A part of this report was read in the 41st Annual Meeting of Japan Endocrinological Society, Kyoto, 1968. and Barraclough (1967) and Hashimoto et al. (1968) confirmed the observation of Eto et al., whereby it was ascertained that a huge amount of progesterone never seen in the estrous cycle (Eto et al., 1962; Hashimoto et al., 1968; Uchida et al., 1969a) nor provided by any treatment with gonadotrophins (Uchida et al., 1969 b) was secreted in midpregnancy. On the other hand, the increasing number of evidences suggest that the progesterone secretion in the 
initial half of pregnancy is sustained by hypophyseal factors, but that the one in the latter half of it by placental or uterine luteotrophic substances. Two peaks of progesterone secretion during pregnancy noted by Fajor and Barraclough (1967) may represent the actions of both luteotrophins from different origins.

In the present experiments, ovarian progesterone and $20 \alpha-\mathrm{OH}-\mathrm{P}$ secretions were measured in detail during pregnancy and pseudopregnancy in relation to the changes in corpora lutea weight, $20 \alpha$-hydroxysteroid dehydrogenase $(20 \alpha-\mathrm{OH}-\mathrm{SDH})$ activity, cholesterol and both progestin concentrations in corpora lutea, since cholesterol (Everett, 1947) and $20 \alpha-\mathrm{OH}-\mathrm{SDH}$ activity (Wiest et al., 1968) in corpora lutea are known to be related to luteal function.

\section{Meterials and Methods}

\begin{abstract}
Animals
Wistar strain female rats weighing 170 to $200 \mathrm{~g}$ were reared with an ordinary rat chow and water $a d$ libitum in an air-conditioned room $\left(25 \pm 1^{\circ} \mathrm{C}, 50-60\right.$ $\%$ humidity) illuminated for $12 \mathrm{hr}$ a day (08.00-20.00 $\mathrm{hr}$ ). Vaginal smears were examined every morning and rats exhibiting a regular 4-day estrous cycle were used after they had completed at least three normal cycles.

In pregnant rats, Day 1 corresponded to the day sperm was found in the vaginal smears. After parturition, rats were kept with pups until the day of experiment. Pseudopregnancy was induced by mating with vasectomized males on the day of proestrus (and the following day was designated as Day 1).
\end{abstract}

Determination of ovarian progesterone and $20 \alpha-$ OH-P secretion

Ovarian secretory rates of progesterone and $20 \alpha-$ $\mathrm{OH}-\mathrm{P}$ were determined at selected days throughout pregnancy or pseudopregnancy and one week after parturition in lactation according to the method reported in the previous paper (Uchida et al., 1969a).

Determination of tissue cholesterol and phospholipid concentration

Ovaries were removed from intact pregnant rats under sodium methylhexabital anesthesia $(125 \mathrm{mg} / \mathrm{kg}$, i.p.) and corpora lutea were separated from the remaining ovarian tissues. The isolated corpora lutea were immediately weighed on a torsion balance, homogenized in a cold mixture of acetone-ethanol $(1: 1)$ in Potter-Elvehjem homogenizers, and filtered through Toyo Filter Paper No. 131. Aliquots of the filtrates, usually one to two tenths of the total, were served for cholesterol and phospholipid determinations. Tissue extracts were evaporated to dryness under a stream of nitrogen and hydrolyzed in a $2 \mathrm{ml}$ of $15 \%$ potassium hydroxide in $50 \%$ ethanol at $70^{\circ} \mathrm{C}$ for $15 \mathrm{~min}$. Unsaponified sterols were extracted with a 5 $\mathrm{m} l$ volume of petroleum ether three times. Cholesterol was determined by the method of Zlatkis et al. (1953). Phospholipid in tissue extracts was determined by perchloric acid oxidation method (Gomori, 1942).

Determination of tissue progesterone and $20 \alpha-O H$ $P$ concentration

Corpora lutea isolated from individual rats were homogenized in $8 \mathrm{~m} l$ of $1 \%$ sodium hydroxide in a similar manner as reported by Wiest (1970) and subjected to the analysis of both progestins. The determination procedures are the same as that for blood progestins (Uchida et al., 1969a).

$20 \alpha-H y d o x y s t e r o i d$ dehydrogenase $(20 \alpha-O H-S D H)$ activity

Ovarian tissue distribution of $20 \alpha-\mathrm{OH}-\mathrm{SDH}$ activity was examined histochemically by the method of Balough (1964).

\section{Results}

\section{Progestin secretion during pregnancy and after parturition}

Table 1 presents the data on ovarian secretory rates of progesterone and $20 \alpha-\mathrm{OH}-\mathrm{P}$, and on the ratios of progesterone to total progestin (progesterone plus $20 \alpha-\mathrm{OH}-\mathrm{P}$ ) determined on selected days during pregnancy and after parturition. The pattern of the secretory rate of both progestins is illustrated in Figure 1. Progesterone secretion still remained low on Days 1 and 2, but apparently increased on Day 3 and formed the first peak on Day 4 giving the value $4.49 \mu \mathrm{g} / \mathrm{hr}$ /ovary which was about 8 times higher than the value on Day 1. Then, progesterone secretion declined to the value of 1.68 on Day 7 , but increased again on Day 10, attained the maximum value of 11 to $12 \mu \mathrm{g} / \mathrm{hr} /$ ovary from Day 13 through Day 15, and thereafter reduced to the value of 0.67 on Day 22. Most 
Table 1. Ovarian secretory rates of progesterone and $20 \alpha$-hydroxypregn-4-en-3-one (20 $\alpha$-OH-P) during pregnancy and after parturition in rats

\begin{tabular}{|c|c|c|c|c|c|c|}
\hline $\begin{array}{l}\text { Day of } \\
\text { pregnancy }\end{array}$ & $\begin{array}{l}\text { No. } \\
\text { of } \\
\text { rats }\end{array}$ & $\begin{array}{l}\text { Body weight } \\
(\mathrm{g})\end{array}$ & $\begin{array}{l}\text { Ovary } \\
(\mathrm{mg} \%)\end{array}$ & \multicolumn{2}{|c|}{$\begin{array}{c}\text { Secretory rate of progestins } \\
(\mu \mathrm{g} / \mathrm{hr} / \text { ovary })\end{array}$} & $\begin{array}{c}\text { Progesterone } \\
\text { ratio } \\
(\%)\end{array}$ \\
\hline 1 & 10 & $194 \pm 2.5^{b)}$ & $42 \pm 1.5^{b)}$ & $0.59 \pm 0.15^{\mathrm{b})}$ & $\left.5.76 \pm 0.80^{b}\right)$ & $8 \pm 3.2^{b)}$ \\
\hline 2 & 9 & $197 \pm 4.8$ & $31 \pm 1.4$ & $0.84 \pm 0.18$ & $2.78 \pm 0.46$ & $22 \pm 4.7$ \\
\hline 3 & 8 & $205 \pm 4.4$ & $35 \pm 0.9$ & $3.84 \pm 0.59$ & $3.82 \pm 0.79$ & $52 \pm 6.3$ \\
\hline 4 & 6 & $206 \pm 13.4$ & $34 \pm 2.3$ & $4.49 \pm 0.96$ & $2.42 \pm 0.71$ & $67 \pm 1.7$ \\
\hline 5 & 5 & $200 \pm 11.0$ & $34 \pm 1.4$ & $2.82 \pm 0.72$ & $0.79 \pm 0.16$ & $75 \pm 3.5$ \\
\hline 7 & 6 & $198 \pm 4.5$ & $30 \pm 2.0$ & $1.68 \pm 0.41$ & $0.95 \pm 0.21$ & $63 \pm 7.5$ \\
\hline 10 & 10 & $216 \pm 4.9$ & $29 \pm 0.7$ & $4.19 \pm 0.76$ & $0.86 \pm 0.25$ & $83 \pm 1.7$ \\
\hline 13 & 7 & $245 \pm 8.6$ & $32 \pm 1.6$ & $11.74 \pm 2.21$ & $1.42 \pm 0.20$ & $89 \pm 1.3$ \\
\hline 15 & 9 & $243 \pm 6.2$ & $37 \pm 1.2$ & $11.18 \pm 2.11$ & $3.65 \pm 0.82$ & $76 \pm 1.6$ \\
\hline 18 & 10 & $264 \pm 5.4$ & $37 \pm 1.5$ & $7.57 \pm 1.09$ & $2.10 \pm 0.31$ & $77 \pm 2.2$ \\
\hline 20 & 10 & $266 \pm 10.2$ & $36 \pm 1.8$ & $2.02 \pm 0.37$ & $2.34 \pm 0.48$ & $46 \pm 3.8$ \\
\hline 21 & 7 & $281 \pm 15.7$ & $38 \pm 1.2$ & $2.98 \pm 0.64$ & $1.89 \pm 0.42$ & $51 \pm 9.2$ \\
\hline 22 & 11 & $302 \pm 8.3$ & $36 \pm 1.2$ & $0.67 \pm 0.11$ & $4.39 \pm 0.79$ & $18 \pm 4.6$ \\
\hline $23^{c)}$ & 9 & $207 \pm 6.5$ & $46 \pm 2.8$ & $1.17 \pm 0.30$ & $8.76 \pm 1.69$ & $11 \pm 1.9$ \\
\hline 24 & 9 & $224 \pm 5.9$ & $44 \pm 2.2$ & $0.66 \pm 0.19$ & $9.14 \pm 1.65$ & $7 \pm 1.3$ \\
\hline 25 & 7 & $236 \pm 6.4$ & $37 \pm 1.7$ & $3.26 \pm 0.91$ & $5.81 \pm 1.25$ & $35 \pm 7.1$ \\
\hline 27 & 9 & $237 \pm 7.3$ & $36 \pm 0.9$ & $7.33 \pm 1.01$ & $4.74 \pm 0.76$ & $61 \pm 1.7$ \\
\hline
\end{tabular}

a) Progesterone / total progestin (sum of progesterone and $20 \alpha-\mathrm{OH}-\mathrm{P}$ ) ratio in $\%$.

b) Mean \pm S.E.

c) The day of parturition.

of pregnancies terminated on Day 23. After parturition, progesterone secretion increased again from Day 25 which corresponded to Day 3 after parturition and gave a high value as $7.33 \mu \mathrm{g} / \mathrm{hr}$ /ovary on Day 27 (Day 5 after parturition). Thereafter, no experiment was performed.

On the contrary, $20 \alpha-\mathrm{OH}-\mathrm{P}$ secretion decreased from Day 2 on and remained low throughout the period of pregnancy, although a small peak was observed around Day 15 . The secretion of $20 \alpha-\mathrm{OH}-\mathrm{P}$ increased from Day 22 a day before parturition, to the maximum on Day 24 (Day 2 after parturition) but decreased again in accordance with the increase in progesterone secretion (Fig. 1).

In general, progesterone and $20 \alpha-\mathrm{OH}-\mathrm{P}$ secretions appeared to change in the opposite direction as clearly seen in the beginning of pregnancy (Day 1 through Day 4) or at the termination of pregnancy (Day 21 through Day 27). However, this was not always true, since the depression in progesterone secretion on Day 7 and at late pregnancy (Day 18 through Day 21) was not accompanied by the increase in $20 \alpha-\mathrm{OH}-\mathrm{P}$ secretion (Fig. 1).

\section{Progestin secretion during pseudopregnancy}

Ovarian secretory rates of progesterone and $20 \alpha-\mathrm{OH}-\mathrm{P}$ during pseudopregnancy are given in Table 2. Progesterone secretion increased from Day 3 to the maximum on Day 7 and thereafter declined to the lowest value on Day 14. The secretion of $20 \alpha-\mathrm{OH}-\mathrm{P}$ decreased from Day 4, remained low till Day 12, and restored to the initial level on Day 13.

Although $20 \alpha-\mathrm{OH}-\mathrm{P}$ secretion decreased during pseudopregnancy, the values were higher than the value during the corresponding days of pregnancy. Therefore, the progesterone/total progestin ratios were higher in pregnancy.

Corpora lutea weight, $20 \alpha-O H-S D H$ activity and concentrations of cholesterol and phos- 


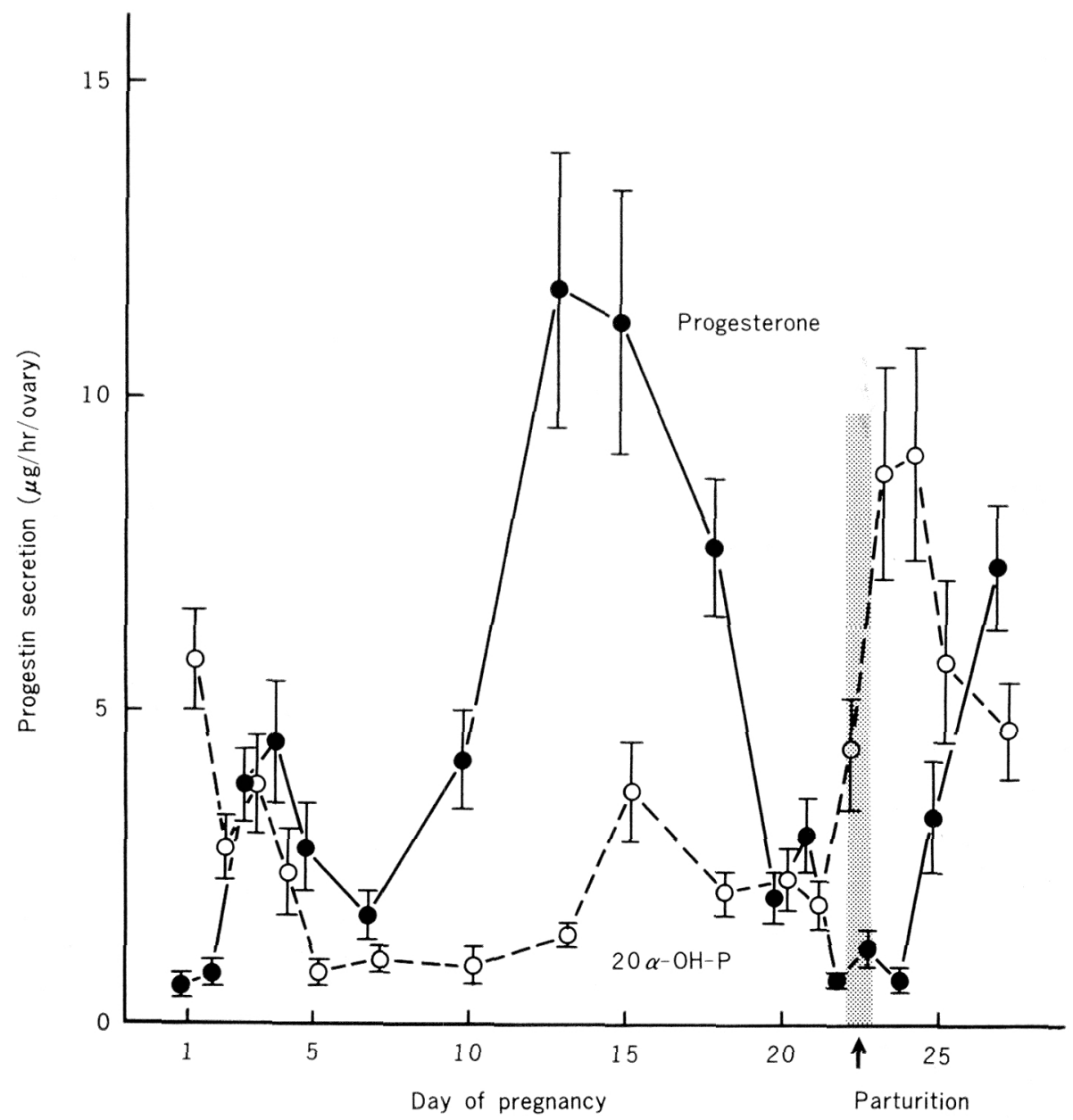

Fig. 1. Ovarian secretory rates of progesterone and 20 $\alpha$-hydroxypregn-4-en-3-one (20 $\alpha$ $\mathrm{OH}-\mathrm{P})$ during pregnancy and after parturition in rats.

Table 2. Ovarian secretory rates of progesterone and $20 \alpha$-hydroxypregn-4-en-3-one (20 $\alpha$-OH-P) during pseudopregnancy in rats

\begin{tabular}{crclccc}
\hline $\begin{array}{c}\text { Day of } \\
\text { pseudo- } \\
\text { pregnancy }\end{array}$ & $\begin{array}{c}\text { No. } \\
\text { of } \\
\text { rats }\end{array}$ & $\begin{array}{c}\text { Body weight } \\
(\mathrm{g})\end{array}$ & $\begin{array}{c}\text { Ovary } \\
(\mathrm{mg} \%)\end{array}$ & \multicolumn{2}{c}{$\begin{array}{c}\text { Secretory rate of progestins } \\
(\mu \mathrm{g} / \mathrm{hr} / \text { ovary })\end{array}$} & $\begin{array}{c}\text { Progesterone } \\
\text { Progesterone }\end{array}$ \\
\hline 1 & 9 & $199 \pm 7.4^{\mathrm{b})}$ & $37 \pm 1.6^{\mathrm{b})}$ & $0.59 \pm \mathbf{0 . 1 3 ^ { \mathrm { b } } )}$ & $6.45 \pm 0.66^{\mathrm{b})}$ & $8 \pm 1.2^{\mathrm{b})}$ \\
3 & 9 & $200 \pm 4.2$ & $32 \pm 1.8$ & $3.82 \pm 0.88$ & $6.94 \pm 1.44$ & $36 \pm 3.9$ \\
4 & 8 & $200 \pm 5.7$ & $29 \pm 1.2$ & $3.73 \pm 0.65$ & $2.69 \pm 0.41$ & $57 \pm 2.5$ \\
5 & 10 & $220 \pm 6.5$ & $31 \pm 1.5$ & $4.31 \pm 0.59$ & $3.13 \pm 0.67$ & $61 \pm 3.4$ \\
7 & 9 & $221 \pm 6.6$ & $30 \pm 1.3$ & $5.20 \pm 1.05$ & $3.28 \pm 0.57$ & $59 \pm 3.2$ \\
10 & 10 & $223 \pm 6.5$ & $27 \pm 0.6$ & $2.22 \pm 0.39$ & $2.11 \pm 0.25$ & $45 \pm 4.4$ \\
12 & 8 & $246 \pm 7.8$ & $27 \pm 0.8$ & $1.01 \pm 0.28$ & $2.72 \pm 0.35$ & $29 \pm 3.9$ \\
13 & 6 & $231 \pm 8.6$ & $27 \pm 1.2$ & $1.15 \pm 0.40$ & $6.38 \pm 1.52$ & $17 \pm 3.7$ \\
14 & 9 & $223 \pm 6.0$ & $28 \pm 1.2$ & $0.41 \pm 0.06$ & $5.56 \pm 0.62$ & $8 \pm 1.4$ \\
\hline
\end{tabular}

a) Progesterone / total progestin ratio in \%.

b) Mean \pm S.E. 
Table 3. Average corpus luteum weight and concentrations of cholesterol and phospholipid in corpora lutea during pregnancy in rats

\begin{tabular}{ccccc}
\hline $\begin{array}{c}\text { Day of } \\
\text { pregnancy }\end{array}$ & No. of rats & $\begin{array}{c}\text { Average corpus } \\
\text { luteum weight } \\
(\mathrm{mg})\end{array}$ & $\begin{array}{c}\text { Cholesterol } \\
(\mathrm{mg} / \mathrm{g})\end{array}$ & $\begin{array}{c}\text { Phospholipid } \\
(\mathrm{mg} / \mathrm{g})\end{array}$ \\
\hline 5 & 3 & $1.36 \pm 0.07^{\mathrm{a})}$ & $8.5 \pm 0.40^{\mathrm{a})}$ & $69.5 \pm 9.29^{\mathrm{a})}$ \\
7 & 4 & $1.38 \pm 0.02$ & $7.9 \pm 0.26$ & $74.5 \pm 2.90$ \\
8 & 9 & $1.40 \pm 0.03$ & $7.4 \pm 0.37$ & \\
10 & 4 & $1.46 \pm 0.13$ & $9.6 \pm 0.76$ & \\
11 & 4 & $1.59 \pm 0.09$ & $8.1 \pm 0.42$ & \\
12 & 6 & $1.85 \pm 0.09$ & $10.0 \pm 0.57$ & \\
13 & 7 & $2.42 \pm 0.06$ & $10.9 \pm 1.09$ & \\
14 & 4 & $3.00 \pm 0.09$ & $11.6 \pm 0.97$ & \\
15 & 10 & $3.72 \pm 0.13$ & $10.9 \pm 0.79$ & \\
16 & 10 & $4.05 \pm 0.08$ & $10.7 \pm 0.52$ & \\
17 & 11 & $3.96 \pm 0.10$ & $11.9 \pm 0.66$ & \\
18 & 8 & $3.92 \pm 0.27$ & $20.8 \pm 4.50$ & \\
20 & 4 & $4.27 \pm 0.22$ & $22.1 \pm 3.82$ & \\
22 & 3 & $3.94 \pm 0.30$ & $25.5 \pm 5.24$ & \\
23 & 5 & $4.38 \pm 0.21$ & $17.7 \pm 3.73$ & \\
\hline
\end{tabular}

a) Mean \pm S.E.

\section{pholipid during pregnancy}

A pair of ovaries usually contained 10 to 17 newly formed corpora lutea. These corpora lutea were isolated from the remaining ovarian tissues to determine their average weight and concentrations of cholesterol and phospholipid on the selected days during and after pregnancy. The data are given in Table 3. Values of the weight and cholesterol concentration are plotted on a graph throughout pregnancy and their changes are compared with those in ovarian progestin secretory rates in Figure 2.

The mean corpus luteum weight was initially about $1.4 \mathrm{mg}$ and remained fairly constant till Day 10. However, it started to increase on Day 11 and reached the maximum on Day 16. Thereafter it stayed at elevated values around $4.0 \mathrm{mg}$ until Day 23. The marked ovarian progesterone secretion occurred in coincidence with the increasing weight gain of the corpora lutea (from Day 12 through 15) and the decline in progesterone secretion took place with the cessation of corpora lutea growth (Fig. 2). A small peak of $20 \alpha-\mathrm{OH}-\mathrm{P}$ secretion was also seen at the time of the maximal hypertrophy of the corpora lutea on Day 15.
Ovarian $20 \alpha-\mathrm{OH}-\mathrm{SDH}$ activity was examined histochemically on Days 15, 20, 21, 22, and 23 of pregnancy, and the activities in corpora lutea were qualitatively shown in Figure 2. In the ovaries on Day 15, the activity of this enzyme was found in older corpora lutea which were probably formed in the previous estrous cycle or older, interstitial glands and theca cells in follicules, but not found in younger corpora lutea. The activity in younger corpora lutea, presumed to be functional, was first found on Day 21 and progressively increased thereafter.

Cholesterol concentration showed a gradual increase with a gentle slope till Day 17 followed by a marked elevation on Day 18, and the elevated level was maintained until Day 23 (the day parturition was expected) although a slight decrease was noticed on the last day of pregnancy. A striking increase in the cholesterol concentration on Day 18 was noteworthy since it was so striking as to almost double the value on the previous day $(11.9 \mathrm{mg} / \mathrm{g}$ on Day 17 vs. $20.8 \mathrm{mg} / \mathrm{g}$ on Day 18$)$.

Phospholipid concentration in corpora lutea, however, remained unchanged through- 


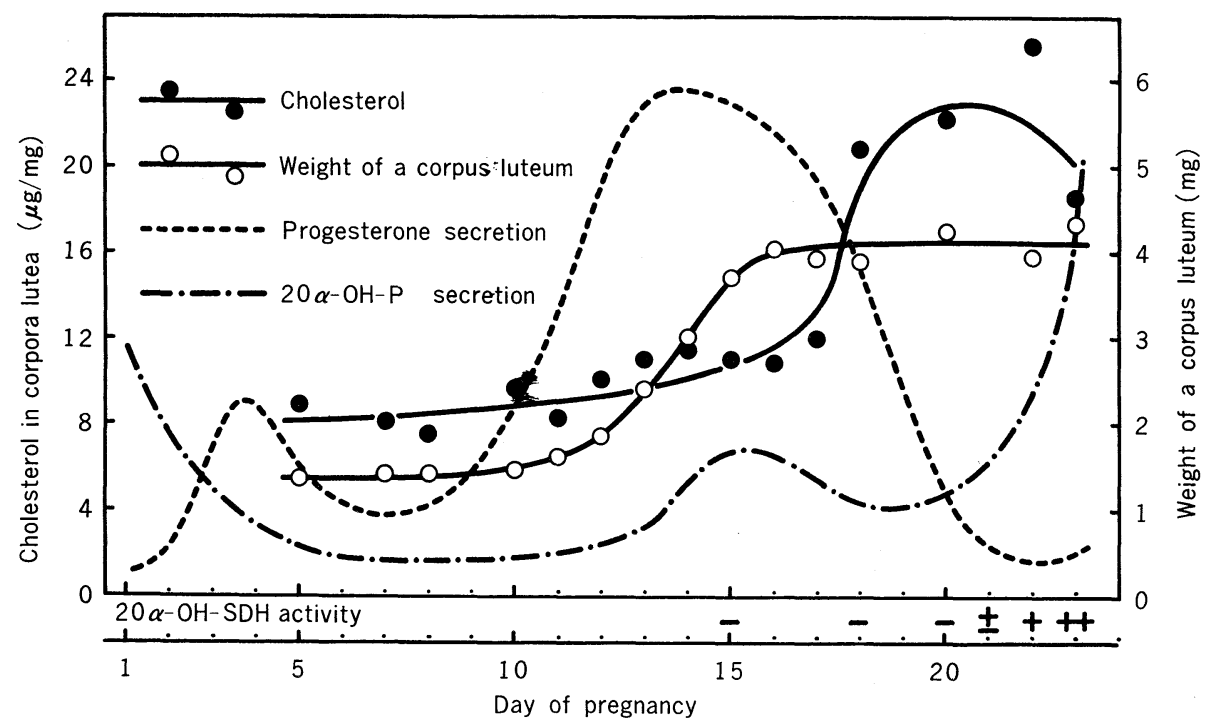

Fig. 2. Changes of corpora lutea weights, cholesterol concentrations, $20 \alpha$-hydroxysteroid dehydrogenase $(20 \alpha-\mathrm{OH}-\mathrm{SDH})$ activities, and ovarian secretory rates of progesterone and $20 \alpha$-hydroxypregn-4-en-3-one (20 $\alpha$-OH-P) during pregnancy in rats. $20 \alpha-\mathrm{OH}-\mathrm{SDH}$ activities in corpora lutea were expressed as negative $(-)$, slightly positive $( \pm)$, positive $(+)$, and strongly positive $(++)$.

out pregnancy (Table 3 ).

Progestin concentration in corpora lutea during pregnancy

Progesterone and $20 \alpha-\mathrm{OH}-\mathrm{P}$ concentrations in the corpora lutea are presented in Table 4. Although values somewhat flucuated, progesterone concentration was high in earlier pregnancy and decreased according to the progress of pregnancy. The concentration of $20 \alpha-\mathrm{OH}-\mathrm{P}$ fluctuated with so much larger amplitude that a certain tendency of its change during pregnancy was not obtained.

\section{Discussion}

The present data obtained in regard to progestin secretion confirm the earlier findings (Eto et al., 1962; Fajor and Barraclough, 1967; Hashimoto et al., 1968) and more definitely distinguish the characteristic events in ovarian secretion of progesterone and $20 \alpha-\mathrm{OH}-\mathrm{P}$
Table 4. Progesterone and 20 $\alpha$-hydroxypregn-4-en3 -one concentrations in corpora lutea during pregnancy in rats

\begin{tabular}{crrr}
\hline $\begin{array}{c}\text { Day of } \\
\text { pregnancy }\end{array}$ & $\begin{array}{c}\text { No. of } \\
\text { rats }\end{array}$ & $\begin{array}{c}\text { Progesterone } \\
(\mu \mathrm{g} / \mathrm{g})\end{array}$ & $\begin{array}{c}20 \alpha-\mathrm{OH}-\mathrm{P} \\
(\mu \mathrm{g} / \mathrm{g})\end{array}$ \\
\hline 5 & 6 & $26.0 \pm 3.70^{\mathrm{a})}$ & $\left.16.7 \pm 2.09^{\mathrm{a}}\right)$ \\
8 & 5 & $28.0 \pm 1.64$ & $20.6 \pm 0.65$ \\
10 & 5 & $16.9 \pm 1.61$ & $8.6 \pm 0.62$ \\
15 & 8 & $16.0 \pm 1.58$ & $19.9 \pm 1.04$ \\
17 & 10 & $8.7 \pm 1.53$ & $23.7 \pm 5.19$ \\
18 & 11 & $7.5 \pm 0.82$ & $31.9 \pm 4.01$ \\
20 & 6 & $12.6 \pm 0.75$ & $20.0 \pm 1.23$ \\
23 & 6 & $3.2 \pm 0.55$ & $19.8 \pm 3.27$ \\
24 & 6 & $6.6 \pm 0.26$ & $18.5 \pm 1.44$ \\
\hline
\end{tabular}

a) Mean \pm S.E.

during both pregnancy and pseudopregnancy by detailed experiments, although some minor differences are observed between the earlier reports and the present data, which may be due to differences in the strain of rats used; the lighting schedule, or the time of determination. The followings are the results 
generally conclusive: 1) Progesterone secretion during pregnancy begins to increase on Day 3 to make the first minor peak on Day 4 and the second major peak between Day 13 and 15 after a fall on Day 7 and terminates a day before parturition. 2) Progesterone secretion during pseudopregnancy also increases on Day 3 , forms a single peak on Day 7 and finishes a day before the end of prolonged vaginal diestrus. 3) The secretion of $20 \alpha-\mathrm{OH}-\mathrm{P}$ decreases throughout the period of both pregnancy and pseudopregnancy, and restores to or over the initial level a day before the termination, although the secretion of $20 \alpha-\mathrm{OH}-\mathrm{P}$ forms a small peak around Day 15 of pregnancy. 4) The progesterone/total progestin (sum of progesterone and $20 \alpha-\mathrm{OH}-\mathrm{P}$ ) ratio is higher in pregnancy than in pseudopregnancy, because of a higher $20 \alpha-\mathrm{OH}-\mathrm{P}$ secretion in pseudopregnancy.

That the marked increase in cholesterol concentration in the corpora lutea on Day 18 occurred in coincidence with the decrease in progesterone secretion (Fig. 2) suggests that the functional luteolysis of the pregnant corpora lutea begins on this day. It has been recognized in pregnant rats that LH treatment causes a marked deposition of cholesterol in corpora lutea (Everett, 1947) and an increase in both luteal $20 \alpha-\mathrm{OH}-\mathrm{SDH}$ activity and plas-

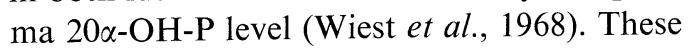
changes are conceivable as the signs of luteolysis of corpora lutea. Wiest and his coworkers (Wiest et al., 1968; Hashimoto and Wiest, 1969) have extended their experiments to emphasize the role of ovarian $20 \alpha-\mathrm{OH}-\mathrm{SDH}$ in the luteolytic process which involves the conversion of progesterone to $20 \alpha-\mathrm{OH}-\mathrm{P}$ with no change in the amount of total progestins. However, in our pregnant rats, a fall of progesterone secretion definitely occurs on Day 18 without any increase either in luteal $20 \alpha-$ $\mathrm{OH}-\mathrm{SDH}$ activity or in ovarian $20 \alpha-\mathrm{OH}-\mathrm{P}$ secretion (Table 1 and Fig. 2). The earlier reports in other laboratories (Fajor and Barraclough, 1967, Hashimoto et al., 1968) have also noted the depression of progesterone secretion on this day. In our histochemical experiments, the distinguishable appearance of $20 \alpha-\mathrm{OH}-\mathrm{SDH}$ activity in corpora lutea was first found on Day 21. The increase in this enzyme activity corresponds very well with the rise in ovarian 20 $\alpha-\mathrm{OH}-\mathrm{P}$ (Fig. 2; Wiest et al., 1968). Thus, the causual relationship between corpora lutea cholesterol concentration, ovarian $20 \alpha-\mathrm{OH}-\mathrm{SDH}$ activity, and ovarian progestin secretion leads us to conclude that the drop in progesterone secretion results in a deposition of cholesterol in the corpora lutea and the increase in $20 \alpha-\mathrm{OH}-\mathrm{SDH}$ activity, which occurs 3 or 4 days later, brings a rise of $20 \alpha-\mathrm{OH}-\mathrm{P}$ secretion independently of progesterone secretion.

Although it has been well accepted that $20 \alpha-\mathrm{OH}-\mathrm{P}$ is formed by the reduction of progesterone, the amount of precursor enough to be responsible for the increase of $20 \alpha-\mathrm{OH}-$ $\mathrm{P}$ secretion on Day 21 to 23 does not seem to be provided, because the corpora lutea at this time have already lost the mechanism to produce progesterone and no special increase in the concentration of both progesterone and $20 \alpha-\mathrm{OH}-\mathrm{P}$ is found in the corpora lutea (Table 4) or in the ovary (Wiest, 1970). Since $20 \alpha-\mathrm{OH}-\mathrm{SDH}$ can reduce pregnenolone or other 20-ketonic steroids to pregn-5-ene-3 $\beta$, $20 \alpha$-diol or corresponding $20 \alpha$-hydroxysteroids, the $20 \alpha-\mathrm{OH}-\mathrm{P}$ which has increased at the end of pregnancy (Day 22-25) may be formed from precursor(s) other than progesterone through the pathway including $20 \alpha$-hydroxylation process, or, alternatively, from progesterone which, however, should be provided by a different way from that in midpregnancy.

The first rise of progesterone secretion on Day 4 of pregnancy as well as the progesterone secretion in pseudopregnancy is probably sustained by luteotrophic hormone released from the pituitary and the fall of progesterone secretion on Day 7 may be due to the reduced secretion of luteotrophic hormone (Table 1). This fall has been considered as the result from the luteolytic effect of LH which may be released to stimulate estrogen secretion at 
this time (Fajor and Barraclough, 1967). Actually, LH caused luteolysis (Rothchild, 1967; Wiest et al., 1968; Hashimoto and Wiest, 1969) and antagonized the luteotrophic action of LTH (Malven et al., 1967). Further, the presence of $\mathrm{LH}$ and its phisiological significance in early pregnancy were demonstrated by the aid of anti-LH serum (Madhwa Raj et al., 1967; Loewit et al., 1969). However, the level of $\mathrm{LH}$ at this period was too low to be detected by ovarian ascorbic acid depletion method in our rats (F. Kobayashi et al., unpublished data). It is doubtful, therefore, whether such a small amount of LH can antagonize the action of LTH to cause luteolysis, because neither the increased cholesterol deposition in corpora lutea (Fig.

2) nor the increased $20 \alpha-\mathrm{OH}-\mathrm{SDH}$ activity in the ovary (Wiest et al., 1968) has been shown in early pregnancy. The elevated progesterone secretion keeps at least 3 days longer in pseudopregnancy, when compared with the secretion pattern in the first week of normal pregnancy, suggesting that some uterine factors relating to implantation and subsequent events may be responsible for the depression of progesterone secretion rate around the time of ova-implantation.

During pregnancy, the placenta is considered to produce luteotrophic substances (Astwood and Greep, 1938; Ray et al., 1955) since hypophysectomy on Day 11 or later does not interrupt pregnancy (Pencharz and Long, 1933; Pencharz and Lyons, 1934). Day 11 corresponds with the time of development of the placenta in this species. Furthermore, there are some observations indicating the influence of placental or uterine substances on the ovarian progesterone secretion in rats; placental dislocation causes a prompt regression in the corpora lutea (Wiest et al., 1968), and diciduoma formation (Melampy et al., 1964) or hysterectomy (Melampy et al., 1964; Hashimoto et al., 1968) extends the period of pseudopregnancy as well as ovarian progesterone secretion (Hashimoto et al., 1968). It is likely, therefore, that the second peak of progesterone secretion seen after Day 7 is due to the luteotrophic substances originated from the placenta or uterus. This conception is supported by the recent observation of Turolla et al. (1970) that hypophysectomy in early pregnancy or hysterectomy in late pregnancy increases $20 \alpha-\mathrm{OH}-\mathrm{SDH}$ activity in corpora lutea, whereas hypophysectomy in late pregnancy or hysterectomy in early pregnancy does not. Loewit et al. (1969) also showned that the treatment with anti-LH serum during early pregnancy resulted in termination of pregnancy with the increase of $20 \alpha-\mathrm{OH}-\mathrm{SDH}$ activity in the corpora lutea, while the treatment during late pregnancy neither interrupted pregnancy nor increased $20 \alpha-\mathrm{OH}-\mathrm{SDH}$ activity.

As seen in Figure 2, the growth of corpora lutea closely relates to the increase in both progesterone and $20 \alpha-\mathrm{OH}-\mathrm{P}$ secretion. The progesterone secretion during the period from Day 13 to 15 is about 2.5-fold higher than that on Day 4, but the ratios of progesterone secretory rate to the average corpus luteum weight are found to be almost comparable between Day 4 and Day 13-15 (Table 5). The hypertrophy of lutein cells, therefore, may account for the second peak of progesterone secretion being higher than the first, and also for the increased $20 \alpha-\mathrm{OH}-\mathrm{P}$ secretion around Day 15 without appearance of $20 \alpha-\mathrm{OH}-\mathrm{SDH}$ activity in corpora lutea.

After parturition, a marked increase in

Table 5. Average corpus luteum weight, progesterone secretory rate, and their ratio on Days 4,13 , and 15 of pregnancy

\begin{tabular}{clcc}
\hline $\begin{array}{c}\text { Day of } \\
\text { pregnancy }\end{array}$ & $\begin{array}{c}\text { Average } \\
\text { corpus luteum } \\
\text { weight } \\
(\mathrm{mg})\end{array}$ & $\begin{array}{c}\text { Progesterone } \\
\text { secretory } \\
\text { rate } \\
(\mu \mathrm{g} / \mathrm{hr} / \text { ovary) }\end{array}$ & Ratio $^{\mathrm{a})}$ \\
\hline 4 & $1.36^{\mathrm{b})}$ & 4.49 & 3.30 \\
13 & 2.42 & 11.74 & 4.86 \\
15 & 3.72 & 11.18 & 3.05 \\
\hline
\end{tabular}

a) Progesterone secretory rate/average corpus luteum ratio.

b) The value on Day 5 (cf. Fig. 2). 
progesterone secretion occurs on Day 3 conversely with a rapid decrease in $20 \alpha-\mathrm{OH}-\mathrm{P}$ secretion (Table 1), confirming the previous reports (Eto et al., 1962; Tomogane et al., 1969). These changes are considered to be due to the newly formed corpora lutea after post-partum ovulation which is known to occur shortly after parturition (Blandau and Soderwall, 1941) by the post-partum LH release (Rebar et al., 1969).

\section{References}

Astwood, E. B. and R. O. Greep (1938). Proc. Soc. Exptl. Biol. Med. 38, 713.

Balogh, K. Jr. (1964). J. Histochem. Cytochem. 12, 670.

Blandau, R. J. and A. L. Soderwall (1941). Anat. Rec. 81, 419.

Eto, T., H. Masuda, Y. Suzuki and T. Hoshi (1962). Jap. J. Anim. Reprod. 8, 34.

Everett, J. W. (1947). Endocrinology 41, 364.

Fajor, A. B. and C. A. Barraclough (1967). Ibid. 81, 617.

Gomori, G. (1942). J. Lab. Clin. Med. 27, 955.

Hashimoto, I., D. M. Henricks, L. L. Anderson and R. M. Melampy (1968). Endocrinology 82, 333.

Hashimoto, I. and W. G. Wiest (1969). Ibid. 84, 886.
Loewit, K., S. Badawy and K. Laurence (1969). Ibid. 84, 244.

Madhwa Raj, H. G., M. R. Sairam and N. R. Moudgal (1968). J. Reprod. Fert. 17, 335. Malven, P. V., W. Hansel and C. H. Sawyer (1967). Ibid. 13, 205.

Melampy, R. M., L. L. Anderson and C. L. Kragt (1964). Endocrinology 74, 501.

Pencharz, R. I. and J. A. Long (1933). Am. J. Anat. 53, 117.

Pencharz, R. I. and W. R. Lyons (1934). Proc. Soc. Exptl. Biol. Med. 31, 1131.

Ray, E. W., S. C. Averill, WM. R. Lyons and R. E. Johnson (1955). Endocrinology 56, 359.

Reber, R. W., P. K. Nakane and A. R. Midgley, Jr. (1969). Ibid. 84, 1352.

Rothchild, I. (1965). Acta Endocrinol. 49, 107.

Tomogane, H., K. Ota and A. Yokoyama (1969). J. Endocrind. 44, 101.

Turolla, E., G. Baldratti and E. Scrascia (1970). Experientia 26, 418.

Uchida, K., M. Kadowaki and T. Miyake (1969a). Endocrinol. Japon. 16, 227.

Uchida, K., M. Kadowaki and T. Miyake (1969b). Ibid. 16, 239.

Wiest, W. G. (1970). Endocrinology 87, 43.

Wiest, W. G., W. R. Kidwell and K. Balogh, Jr. (1968). Ibid. 82, 844.

Zlatkis, A., B. Zak and A. J. Boyle (1953). J. Lab. Clin. Med. 41, 486. 